\title{
Superficial corneal foreign body: laboratory and epidemiologic aspects
}

\author{
Corpo estranho corneal superficial:aspectos laboratoriais e epidemiológicos
}

\author{
Ednajar Tavares Macedo Filho' \\ Aline Lago ${ }^{2}$ \\ Karine Duarte ${ }^{3}$ \\ Liang' Shih Jung'4 \\ Ana Luísa Höfling' Lima ${ }^{5}$ \\ Denise de Freitas $^{6}$
}

Trabalho realizado no Departamento de Oftalmologia da Universidade Federal de São Paulo (UNIFESP). São Paulo (SP)

${ }^{1}$ Estagiário do Setor de Glaucoma da Universidade Federal de São Paulo (UNIFESP). São Paulo (SP).

${ }^{2}$ Residente do $2^{\circ}$ ano do Departamento de Oftalmologia da UNIFESP. São Paulo (SP).

Residente do $3^{\circ}$ ano do Departamento de Oftalmologia da UNIFESP. São Paulo (SP).

${ }^{4}$ Médico do Departamento de Oftalmologia da UNIFESP. São Paulo (SP).

${ }^{5}$ Professora Titular do Departamento de Oftalmologia da UNIFESP. São Paulo (SP)

${ }^{6}$ Livre Docente e Professora Afiliada do Departamento de Oftalmologia da UNIFESP. São Paulo (SP).

Endereço para correspondência: Ednajar T. Macedo Filho - Rua Jaci, 227/64 - São Paulo (SP) CEP 04140-080 E-mail: ednajar@oftalmo.epm.br

Recebido para publicação em 24.05.2005

Versão revisada recebida em 05.08.2005

Aprovação em 15.08.2005

Nota Editorial: Depois de concluída a análise do artigo sob sigilo editorial e com a anuência dos Drs. Samuel Rymer e José Beniz Neto sobre a divulgação de seus nomes como revisores, agradecemos sua participação neste processo.

\begin{tabular}{l} 
ABSTRACT \\
\hline Purpose: To determine by bacterioscopy and culture the microorganisms \\
carried by corneal foreign body and their sensitivity to antibiotics by \\
antibiotic sensitivity test. Methods: A prospective study was carried out \\
and information was collected on 101 patients who presented with \\
corneal foreign body at the São Paulo Hospital Eye Emergency Service. \\
Prior to any treatment, a sample of the ipsilateral inferior conjunctival \\
fornix and the foreign body were collected and immersed in thioglycolate \\
broth. Samples were sown on solid culture media including blood, \\
chocolate and Sabouraud agar. Bacterioscopic examination using Gram \\
and Giemsa staining and sensitivity test were performed. Positive foreign \\
body culture results were compared to ipsilateral conjunctival fornix \\
culture to exclude possible normal flora growth. Results: Approximately \\
92\% of patients were males with a mean age of 35 years and in 62.4\% (95\% \\
confidence interval: 52.2 - 71.8\%) had the right eye was affected. Foreign \\
body positive cultures were achieved in 32.7\% (95\% confidence interval: \\
23.7-42.7\%) of the cases. The microorganisms isolated from the foreign \\
body culture were identified as: Streptococcus, alpha-hemolytic (n=4), \\
Staphylococcus aureus (n=4), Staphylococcus, coagulase-negative \\
(n=4), Corynebacteriumxerosis (n=3), unidentified Gram-positive bacillus \\
(n=2), Moraxella sp (n=1), Serratia sp (n=1), Acynetobacter sp (n=1). \\
The microbial sensitivity test showed that 95\% of the cases were \\
sensitive to chloramphenicol and 90\% were sensitive to ciprofloxacin, \\
these being antibiotics used in our routine service. Conclusion: Superfi- \\
cial corneal foreign body acts as important contaminant vector and the \\
great majority of isolated bacteria were sensitive to the antibiotic prophy- \\
laxis used in the treatment.
\end{tabular}

Keywords: Eye foreign bodies/epidemiology; Eye foreign bodies/drug therapy; Eye injuries/epidemiology; Cornea/injuries; Culture media; Microbial sensitivity tests

\section{INTRODUCTION}

Superficial corneal foreign body is one of the leading cause of preventable ${ }^{(1-3)}$ ocular trauma, affecting mainly young males that work with metallurgy, as locksmiths, mechanics and stoneworkers ${ }^{(4-5)}$.

Besides its economical impact of making the subject be absent from work for a mean period of two days ${ }^{(6-7)}$, it is a potentially deleterious injury which can lead to low visual acuity due to corneal scarring, infectious keratitis and even to endophthalmitis ${ }^{(8-13)}$.

The great majority of corneal foreign bodies are metallic followed in frequency by unknown origin, stone fragments and wood ${ }^{(14)}$. They can act as important vectors of corneal contamination ${ }^{(15-16)}$. 
To the best of our knowledge there are scarce data about the possible role of foreign body as contaminant vehicle in the cornea.

\section{PURPOSE}

To determine the etiologic agents carried by corneal foreign body and their antibiotic sensitivity.

\section{METHODS}

Medical Ethics Committee approval was obtained and all patients gave informed consent. All patients attending the São Paulo Hospital Eye Emergency Service who had not received any treatment including antibiotic drops or ointments and also older than 18 years were asked to volunteer for the study.

A prospective study was carried out and information was collected on 101 patients who presented with corneal foreign body from 20 July to 20 October 2001 . The diagnosis was made by slit lamp examination.

The patients were managed with a standardized treatment. The corneal foreign body and rust ring were removed using a small-gauge hypodermic needle and then the patient was submitted to topical chloramphenicol ointment and firm eye patching.

Prior to any treatment, such as topical anesthesia or removal of foreign body, a sample of the ipsilateral inferior conjunctival fornix was collected using a sterile cotton bud and immersed in thioglycolate broth to assess the normal flora of the eye in study.

After topical anesthesia the foreign body was removed and also immersed in another tube with thioglycolate and both tubes were sent to the External Diseases Laboratory at the Ophthalmology Department of the Federal University of São Paulo.

Both tubes were observed at room temperature until visible turbidity was obtained and so both tube samples were sown on solid culture media including blood, chocolate and Sabouraud agar. After growth in those media bacterioscopic examination using Gram and Giemsa staining and sensitivity test were performed.

Positive foreign body culture results were compared to ipsilateral conjunctival fornix culture to exclude possible normal flora growth.

\section{RESULTS}

During the 3-month study period a total of 101 patients attended the department with corneal foreign body injuries. Of these, 92\% (93/101) were male with a mean age of 35 years, ranging from 18 to 76 years. About $62.4 \%$ [95\% confidence inter$\operatorname{val}(\mathrm{CI}): 52.2-71.8 \%$ ] of patients had their right eye affected.

Foreign body positive cultures were achieved in $32.7 \%$ (95\% CI: $23.7-42.7 \%$ ) of the cases. Coagulase-negative Staphylococcus was the most common isolated microorganism, being present in $15.8 \%$ (95\% CI: 9.3 - 24.4) of patients.
In about $19.8 \%(95 \% \mathrm{CI}: 12.5-28.9 \%)$ of the cases there was no correspondence between the bacteria isolated from the foreign body and the conjunctival fornix culture. The microorganisms isolated from the foreign body culture were identified as: Streptococcus, alpha-hemolytic $(\mathrm{n}=4)$, Staphylococcus aureus $(\mathrm{n}=4)$, Staphylococcus, coagulase-negative $(\mathrm{n}=4)$, Corynebacterium xerosis $(\mathrm{n}=3)$, unidentified Gram-positive bacillus $(\mathrm{n}=2)$, Moraxella $\mathrm{sp}(\mathrm{n}=1)$, Serratia $\mathrm{sp}(\mathrm{n}=1)$, Acynetobacter sp $(\mathrm{n}=1)$.

The sensitivity test showed that $95 \%$ of cases were sensitive to chloramphenicol and $90 \%$ were sensitive to ciprofloxacin, these being antibiotics used in our routine service.

\section{DISCUSSION}

Single or multiple superficial corneal foreign bodies are common in the setting of minor occupational accidents. Literature data are in accordance with our results, superficial corneal foreign bodies being more likely to affect younger males ${ }^{(1-5)}$.

Although trivial, except for their irritative consequences, it is important to view them as potential contaminant vectors, as demonstrated by the finding of $19.8 \%$ culture-positive corneal foreign bodies in our study. The microorganisms isolated from the foreign body cultures included: Streptococcus, alphahemolytic, Staphylococcus aureus, Staphylococcus, coagulase-negative, Corynebacterium xerosis, unidentified Grampositive bacillus, Moraxella sp, Serratia sp, Acynetobacter sp and there was no datum in the literature about carried out isolation and identification of bacteria from superficial corneal foreign bodies. Whether they have real potential to cause infectious corneal ulcers or even endophthalmitis by themselves is yet to be determined.

\section{CONCLUSION}

Superficial corneal foreign body acts as important contaminant vector $(19.8 \%$ of the cases) and the great majority of isolated bacteria were sensitive to the antibiotic prophylaxis used in the treatment.

\section{RESUMO}

Objetivos: Identificar por meio de cultura e bacterioscopia os microrganismos veiculados por corpo estranho corneal e sua sensibilidade aos antibióticos em teste de antibiograma. Métodos: Foi realizado estudo prospectivo em 101 pacientes que procuraram o Pronto-Socorro de Oftalmologia do Hospital São Paulo-UNIFESP/EPM, com diagnóstico de corpo estranho corneal. Previamente a qualquer tratamento o corpo estranho e amostra do fundo de saco conjuntival ipsilateral foram coletados em tubos separados com tioglicolato. Realizou-se semeadura em meios sólidos de ágar sangue, chocolate, Sabouraud e exame bacterioscópico com as colorações de Gram e 
Giemsa e antibiograma. Culturas positivas para o corpo estranho foram comparadas com as de fundo de saco conjuntival para excluir contaminação com flora normal. Resultados: Cerca de $92 \%$ dos pacientes foram do sexo masculino, com idade média de 35 anos. O olho direito foi acometido em 62,4\% (intervalo de confiança 95\%: 52,2 - 71,8\%) da amostra e 32,7\% (intervalo de confiança 95\%: 23,7 - 42,7\%) apresentou crescimento bacteriano positivo em cultura. Os microrganismos encontrados nas culturas dos corpos estranhos foram: Streptococcus, alpha-hemolytic $(\mathrm{n}=4)$, Staphylococcus aureus $(\mathrm{n}=4)$, Staphylococcus, coagulase-negative $(\mathrm{n}=4)$, Corynebacterium xerosis $(\mathrm{n}=3)$, bacilo gram-positivo não identificado $(\mathrm{n}=2)$, Moraxella $\mathrm{sp}(\mathrm{n}=1)$, Serratia $\mathrm{sp}(\mathrm{n}=1)$, Acynetobacter $\mathrm{sp}(\mathrm{n}=1)$. O antibiograma revelou que $95 \%$ dos casos foram sensíveis ao cloranfenicol e $90 \%$ a ciprofloxacina, antibióticos usados na rotina de nosso serviço. Conclusão: $O$ corpo estranho corneal foi importante vetor de contaminação, porém a grande maioria dos microrganismos isolados foi sensível a antibioticoprofilaxia empregada no tratamento.

Descritores: Corpos estranhos no olho/epidemiologia; Corpos estranhos no olho/quimioterapia; Traumatismos oculares/epidemiologia; Córnea/lesões; Meios de cultura; Testes de sensibilidade microbiana

\section{REFERENCES}

1. Nascimento VP, Takei LM, Takahashi WY, Kara José N. Epidemiologia dos atendimentos de 6 meses do Pronto Socorro do Hospital das Clínicas da Faculdade de Medicina da USP [resumo]. Arq Bras Oftalmol. 1999;62:450.
2. Bisnetto OS, Andrade AS, Moreira H, Moreira CA. Traumas óculopalpebrais no Serviço de Pronto Atendimento Oftalmológico do Hospital de Curitiba [resumo]. Arq Bras Oftalmol. 1999;62:495.

3. Romanini F, Ribeiro C, Netto LT, Nassaralla Júnior JJ. Incidência de afecções oculares causadas por acidentes de trabalho em um serviço de referência em Goiânia [resumo]. Arq Bras Oftalmol. 1999;62:507.

4. Bison SHDF, Reggi JRA. Traumas oculares: nosologia de 1.171 casos. Arq Bras Oftalmol. 1995;58(2):105-11.

5. Leal FAM, Silveira DB, Neiva DM, Learth JCS. Trauma por corpo estranho extra-ocular em decorrência de atividades profissionais [resumo]. Arq Bras Oftalmol. 1999;62:370.

6. Liu C, Davison C, Cooling R. Eye protection in the metal working industry [letter]. BMJ. 1990;301:1048.

7. More than meets the eye: a study of the time lost from work by patients who incurred injuries from corneal foreign bodies. Br J Ophthalmol. 1991;75 (12):740-2.

8. Sachs SW, Baum J, Mies C. Beauvaria bassiana keratitis. Br J Ophthalmol 1985;69(7):548-50.

9. Lois N, Molino MLP. Mycobacterium chelonae keratitis: resolution after debridment and presoaked collagen shields. Cornea. 1995;14(5):536-9.

10. Huang SC, Soong HK, Chang JS, Liang YS. Non-tuberculous mycobacterial keratitis: a study of 22 cases. Br J Ophthalmol. 1996;80(11):962-8.

11. Wang MX, Shen DJ, Liu JC, Pflugfelder SC, Alfonso EC, Forster RK. Recurrent fungal keratitis and endophthalmitis. Cornea. 2000;19(4):558-60.

12. Domniz Y, Lawless M, Sutton GL, Rogers CM, Meagher LJ. Successful treatment of Paecilomyices lilacinus endophthalmitis after foreign body trauma to the cornea. Cornea. 2001;20(1):109-11.

13. Fogla R, Rao SK, Anand AR, Madhavan HN. Insect wing case: unusual foreign body. Córnea. 2001;20(1):119-21.

14. Leite CR, Wang S, Utida H, Katayama EH, Abreu MT. Estudo de corpo estranho na superfície ocular efetuado em um pronto socorro de Mogi das Cruzes. Arq Bras Oftalmol. 2001;64:109-15.

15. DeBroff BM, Donahue SP, Caputo BJ, Azar MJ, Kowalski RP, Karenchak LM. Clinical characteristics of corneal foreign bodies and their associated culture results. CLAO J. 1994;20(2):128-30.

16. Castanheira VRC, Bechara JS, Lima SR, Kara José N. Corpos estranhos de córnea: estudo epidemiológico e laboratorial [temas livres]. Arq Bras Oftalmol. 1994;57(4):232. 